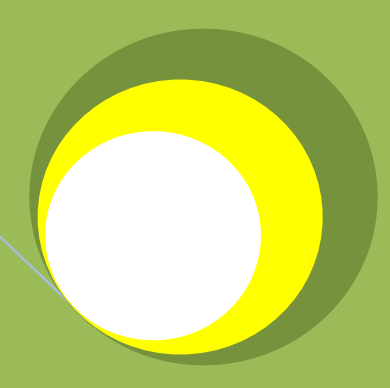

Greener loutmal of Social Sciences

ISSN: 2276-7800

ICV: 5.99

DOI: $\underline{\text { http://doi.org/10.15580/GJSS.2015.2.291114398 }}$

Monitoring

Employees' Use of the Internet in Ladoke

Akintola University of

Technology

Ogbomoso, Oyo State, Nigeria

By

Sobalaje Adewale Joel Adigun Ganiyu Ojo Arinola Adesoji Adeola 


\title{
Monitoring Employees' Use of the Internet in Ladoke Akintola University of Technology Ogbomoso, Oyo State, Nigeria
}

\section{${ }^{1}$ Sobalaje Adewale Joel, ${ }^{\star 2}$ Adigun Ganiyu Ojo and ${ }^{3}$ Arinola Adesoji Adeola}

\author{
1,2,3 Olusegun Oke Library, Ladoke Akintola University of Technology, P.M.B. 4000, Ogbomoso, Oyo \\ State, Nigeria. \\ E-mails: ${ }^{1}$ walesoba@yahoo.com, ${ }^{3}$ sojirinsola@yahoo.com
}

*Corresponding Author's E-mail: adiganfoly@yahoo.com

\begin{abstract}
The study investigated how employees' use of Internet is monitored in Ladoke Akintola University of Technology, Ogbomoso, Oyo state, Nigeria. The study focused on internet access and use, Internet usage and monitoring, policy on personal use of internet in the institution and implementation of policies. It also examined how Internet is restricted and common Internet misuse problems. A structured questionnaire was used to collect data from 350 respondents in the institution out of which 290 (82.9\%) responded and were used for the analysis. Descriptive and Inferential statistics was used to analyze the data using percentage table and simple regression analysis to test the association between the variables. Findings showed that more than half of the respondents have access to and use Internet for their working activities. It was also revealed that most of employees use Local Area Network and Direct subscriber license / Wide area network as their connection type. The study established that higher percentage of the respondents indicated that monitoring of the use of Internet is not practiced. More so small number of the respondents indicated that the institution have written policy on Internet use. It further revealed that just $3.2 \%$ of employee has been dismissed on misuse of institutional web sites. Thus implementation of policy, awareness and compliance with policy is yet to find the right foot in the institution, the study therefore recommended formulation of relevant Internet regulation policy as well as publicizing the policy.
\end{abstract}

Keywords: Internet usage, Internet usage monitoring, Employees, LAUTECH.

\section{INTRODUCTION}

The Internet can be seen as an important by product of Information and Communication Technologies (ICTs). As submitted by Aina (2004), the Internet is a collection of vast information sources of interlinked computer networks, which is usually referred to as network of networks. The Internet is also a worldwide system of interconnected computer networks that use the TCP/IP set of network protocols to reach billions of users. The Internet began as a U.S Department of Defense network to link scientists and university professors around the world. A network of networks, today, the Internet serves as a global data communications system that links millions of private, public, academic and business networks via an international telecommunications backbone that consists of various electronic and optical networking technologies (Investintech.com, 2014). Decentralized by design, no one owns the Internet and it has no central governing authority. As a creation of the Defense Department for sharing research data, this lack of centralization was intentional to make it less vulnerable to wartime or terrorist attacks. The terms "Internet" and "World Wide Web" are often used interchangeably; however, the Internet and World Wide Web are not one and the same. The Internet is a vast hardware and software infrastructure that enables computer interconnectivity. The Web, on the other hand, is a massive hypermedia database - a myriad collection of documents and other resources interconnected by hyperlinks.

The Internet is at once a world-wide broadcasting capability, a mechanism for information dissemination, and a medium for collaboration and interaction between individuals and their computers without regard for geographic location. The Internet represents one of the most successful examples of the benefits of sustained investment and commitment to research and development of information infrastructure (Leiner, et al, 2009). Beginning with the early research in packet switching, the government, industry and academia have been partners in evolving and deploying this exciting new technology. The Internet is the world's biggest computer network, made up of lots of smaller networks, all using the standard Internet Protocol Suite (TCP/IP) to serve billions of users worldwide. It is usually (loosely) called the Net, Information Superhighway or Cyberspace. More formally however, it is described as the Global Information Infrastructure (GII). 
Emergence of the Internet and Information and Communication Technologies (ICTs) can no longer be ignored by institutions and organizations. People bring this technology to the workplace whether institutions or organizations provide it or not. Internet as a tool allows staff and students nearly unlimited access to information. As a venue, it does away with the limits of geography, the time zones and, in some cases, the need for a physical office. The concept of Internet monitoring is generally referred to as the inability of users to access particular online content. Employee monitoring is the act of watching and monitoring employees' actions during working hours using employer devices. While Internet monitoring can be referred to as the act of watching the use of Internet facilities to know if it used for the appropriate activities. A report by the U.S. Office of Technology Assessment, defines computerized performance monitoring as, "the computerized collection, storage, analysis, and reporting of information about employees' productive activities" (Peters, 1999).

The practice of monitoring a company's workers is a controversial practice that is undeniably on the rise (AMA, 2008). When it comes to the subject of employee monitoring there is a grey area; current laws mandate that monitoring is legal, yet the questions of effectiveness and ethics arise. The practice of monitoring staff use of internet is often viewed as activities performed by ICTs management within the institution. Employees' misuse of the internet can be an avenue for virus attacks on organisations system which will slow down performance and might eventually destroy the affected system. However, like any technology, it has its advantages and disadvantages. Effectively managing the risks and maximizing compliance on the new information and communication technologies' (ICTs') proper use requires the development of comprehensive organizational policies (Flynn 2009). Foremost among these are policies on the use of the Internet in the workplace.

\section{Literature Review}

Nowadays, personnel in institutions worldwide use email and the Internet on a daily basis at work. This daily reliance and dependency on technology has created new issues with respect to employee privacy in the workplace and has added new stress to the employer-employee relationship. Employee privacy, considered a basic right, is often taken for granted by employers. However, as a result of technological monitoring, this view may be naïve. According to an a survey by AMA (2001), more than three-quarters of all major U.S. firms (nearly double the 1997 survey results) are recording and/or reviewing the email messages, telephone calls, Internet connections, and computer files of their employees. Workplace monitoring has existed for a long time in one form or another and will undoubtedly continue to proliferate and become increasingly sophisticated as technology advances.

According to Nord, et al (2006) and Pew Internet Survey (2002) as of January 2002, approximately 55 million American adults accessed the Internet at work, up from 43 million in March 2000. 55\% of those with Internet access at work went online on a typical day in 2001, compared to $50 \%$ in 2000 , and many were going online more frequently throughout the day than they had in 2001. Also as reported by Neilson Net Ranking (2006), more than $72 \%$ of Internet users do more than just surf the Web and their popular Internet activities include instant messaging, downloading music, and watching video clips. In another Internet work-related study, Yankelovich Partners (reported by Nord et al, 2006), discovered that $62 \%$ of workers go online at work for personal reasons at least once a day, while about $20 \%$ do so ten or more times a day.

Also in a 2002 study by the Computer Security Institute (CSI), 78\% of polled enterprises reported employee abuse of Internet access privileges by workers, including downloading pirated software or pornography, shopping on the Internet, and inappropriate use of email systems. All these studies and many more not reviewed here are pointing to the escalating magnitude of non-work related Internet use at work. Consequently, employers want to make sure their employees are using company time productively and not creating a legal liability for their business as a result of harassing or offensive communications. A study by Crimmins (2001) revealed that $10 \%$ of American companies have received subpoenas resulting from employee emails. In addition, employers have security concerns relating to the intentional or accidental sending of sensitive data via email attachments as well as the ongoing concern of viruses entering the business from outside communications. As a result of this, employers are monitoring employee's computer and Internet access to a greater degree than in the past. Another study by AMA conducted from 1999 to 2001 and again in 2005, exposed the growing trend of employer monitoring of employees' computer files, email messaging, and Internet connections (AMA, 2005, 2001). According to another AMA survey, the 2003 E-mail Rules, Policies and Practices Survey, over half (52\%) of employers monitor email. Three-fourths of the 1,100 employers surveyed have put written email policies in place. And $22 \%$ have terminated an employee for violating email policy (AMA, 2003).

Alongside its tremendous potential, it has become commonplace for businesses and consumers to utilize the Internet for a variety of transactions ranging from emails to actual online purchases (United Nations, 2007). In many ways, the Internet has made the employees more efficient and has improved communication channels in many organizations. However, the Internet has also opened up new areas of concern such as its effect on workers' productivity. Employees are spending time surfing on the net or communicating with their friends, relative and counterparts during working hours (Ferris, 2000). As observed by Ferris, the following are types of Internet misuse or abuse in the workplace: cyber sexual Internet abuse; online friendship/relationship abuse; Internet activity abuse (e.g., online gambling, online shopping, online travel booking, online computer gaming, 
online day trading, etc.); online information abuse; criminal Internet abuse (e.g., online sexual harassment, cyber stalking, paedophilic "grooming" of children); and miscellaneous Internet abuse (e.g., creating celebrity fake photographs where heads of famous people are superimposed onto someone else's naked body).

The studies reviewed and many more revealed a gap in the literature from Africa and most especially from Nigeria, on the issue of monitoring of employees Internet use by the employers. Most work are from America and other developed worlds and are lacking developing world perspectives, and it is imperative that Nigeria and other Africa nations need to take cognizance of this issue as well as the developed worlds. The above is premise on which this study is based.

\section{Overview of LAUTECH}

Ladoke Akintola University of Technology (also known as LAUTECH) is a technical university located in Ogbomoso, Oyo State, Nigeria. The university currently enrols 25,000 students and employs more than 3,000 people. The main campus is the site of the university's administration, as well as home to six faculties and the post-graduate school. Fields of study include pure and applied sciences, medicine, agriculture, engineering and technology, environmental sciences and management sciences. The University Management has put in place improved Internet bandwidth for the whole of LAUTECH community. The school now has Internet bandwidth on fibre and VSAT links. There is trial Internet for the members of university community since Tuesday 8th march 2007 to date. LAUTECH is currently working on how to expand and improve the reliability and availability of the internal networks in the school.

\section{Problem Statement}

In many ways, the Internet has made the employees more efficient and has improved communication channels in many institutions and organizations. However, the Internet has also opened up new areas of concern such as its effect on workers' productivity. Employees are spending time surfing on the net or communicating with their friends, relative and counterparts during working hours. Indeed, with the entry of younger employees into the workforce, this problem is exacerbated in the light of the "Internet Age" in which they grew up and play with. Undoubtedly, the Internet and e-mail also have given employees a new means of escaping been productive in office. For effective and efficient use of the Internet therefore, it will be necessary to monitor its usage by employees. Hence the need for the study: monitoring employees' use of the Internet in Ladoke Akintola University of Technology, Ogbomoso.

\section{Objectives of the Study}

The general objective of this study is to investigate the issues around the monitoring of employees use of internet in LAUTECH. While other objectives are:

i. To find out the extent to which LAUTECH management regulates internet use,

ii. To find out if there are management internet policies to regulate use of Internet in the institution,

iii. To investigate whether the management internet policies on internet use are made known to employees of the institution, and

iv. To find out the common problems encountered with respect to miss-use of Internet facilities in the institution.

\section{Research Questions}

i. What type of Internet access / connections is in use at LAUTECH by employees?

ii. What is the extent of monitoring employees Internet use in LAUTECH?

iii. Are there existing written policies on regulation / monitoring of employees' Internet use in LAUTECH, how is it implemented and are these made known to employees?

iv. Has misuse of the Internet caused any serious problem(s) to the institution?

The research also tested the following hypothesis:

Ho1: There is no significant relationship between monitoring of employees' Internet usage and awareness of policy on monitoring in LAUTECH, Ogbomoso.

\section{Significance of the Study}

This study will be significant to the LAUTECH management as well as the school's ICT centre, because it will provide empirical evidence on whether the employees are making effective use of the Internet or not. This will assist the management in reviewing existing policy on Internet usage or formulate necessary monitoring policies on Internet usage for its employees if none was in place. 


\section{METHODOLOGY}

There are a lot of research methods that can be adopted in carrying out a research. However, this study adopted the survey design approach. Three hundred and fifty (350) questionnaires were distributed but only two hundred and ninety (290) were returned and was found useful for this study. Statistical Package for Social Sciences (SPSS) was used to analyse the returned questionnaires. Simple percentage table was used to analyse the results, while simple regression analyses was used to test the hypothesis so formulated. Preliminary interviews were also conducted with some ICT administrators regarding their Internet use policies. The respondents who answered the research questions on behalf of the institution were either from the human resource department or the Information Technology/Systems Administration departments of the institution.

Table 1: A summary of the sample sizes and distribution procedures used in the survey

\begin{tabular}{|l|l|l|l|}
\hline $\mathbf{S} / \mathbf{N}$ & Sections in the University & NO. Of Respondents & Percentage (\%) \\
\hline 1 & ICT & $35(40)$ & 12.1 \\
\hline 2 & VC Office & $17(20)$ & 5.9 \\
\hline 3 & Registry & $18(22)$ & 6.2 \\
\hline 4 & Bursary & $15(20)$ & 5.2 \\
\hline 5 & Library & $22(25)$ & 7.6 \\
\hline 6 & Audit & $11(15)$ & 3.8 \\
\hline 7 & Works & $18(20)$ & 6.2 \\
\hline 8 & Health Centre & $16(18)$ & 5.5 \\
\hline 9 & Faculty of Agriculture & $22(25)$ & 7.6 \\
\hline 10 & Faculty of pure Applied Sciences & $21(25)$ & 7.2 \\
\hline 11 & Faculty of Engineering & $20(25)$ & 6.8 \\
\hline 12 & Faculty of Environmental Sciences & $16(20)$ & 5.5 \\
\hline 13 & Faculty of Management Sciences & $18(25)$ & 6.2 \\
\hline 14 & College of Health Sciences & $15(20)$ & 5.2 \\
\hline 15 & Post Graduate School & $26(30)$ & 9.0 \\
\hline & Total & $\mathbf{2 9 0}(350)$ & $\mathbf{1 0 0 . 0}$ \\
\hline
\end{tabular}

From table 1, the number in parenthesis represents the number of questionnaire sent out while the first number represents the responses, i.e. 290 . The return rate was $82.9 \%$.

\section{RESULTS}

\section{Internet Access and Type of Connection the Institution Use}

From the table 2 , it shows that only $62.5 \%$ of the respondents have access to and use Internet for their working activities. It reveals that $98.3 \%$ have Local Area Network as their connection type, Direct Subscriber License / Wide area network 83.3\%, Wireless Fidelity connection 33.3\% and Dial Up (8.3\%).

Table 2: Access and type of Internet connection used in the institution

\begin{tabular}{|l|c|c|}
\hline Variables & Yes (\%) & No (\%) \\
\hline Do you have access to Internet in your office & 62.5 & 37.5 \\
\hline What type of Internet connection & 8.3 & 91.7 \\
\hline Dial up & 33.3 & 66.7 \\
\hline Wireless Fidelity (Wi-Fi) & 98.3 & 1.7 \\
\hline Local Area Network (LAN) & 83.3 & 16.7 \\
\hline $\begin{array}{l}\text { Direct Subscriber License (DSL)/ Wide Area Network } \\
\text { (WAN) }\end{array}$ & 3.3 & 96.7 \\
\hline Others &
\end{tabular}

From table 3, the result shows that $6.7 \%$ said access to Internet was available to employee depending on their job descriptions, $76.6 \%$ said it is available to all employees; and $16.7 \%$ said that Internet was available to the management staff or supervisors. It also shows that $16.7 \%$ of the employees were given some restrictions to Internet access and $83.3 \%$ given complete access. 
Table 3: Who has access and what extent of access to the Internet

\begin{tabular}{|l|l|c|}
\hline Variable & Measurement & Percent (\%) \\
\hline \multirow{3}{*}{$\begin{array}{l}\text { Who has access to Internet in } \\
\text { your institution }\end{array}$} & All & 76.6 \\
\cline { 2 - 3 } & Only management/supervisor & 6.7 \\
\cline { 2 - 3 } & Depending on job & 16.7 \\
\cline { 2 - 3 } & Other arrangement & 0 \\
\cline { 2 - 3 } & Total & 100 \\
\hline \multirow{3}{*}{$\begin{array}{l}\text { What is the extent of access to } \\
\text { the Internet }\end{array}$} & $\begin{array}{l}\text { Complete access } \\
\text { restrictions) }\end{array}$ & 83.3 \\
\cline { 2 - 3 } & Some restrictions & 16.7 \\
\cline { 2 - 3 } & Total & 100 \\
\hline
\end{tabular}

Table 4 shows that more than half $66.7 \%$ of the respondents indicated that monitoring of the use of Internet is not practiced nor was their website connections reviewed. More so only $11.7 \%$ of the respondents are aware of written policy on Internet use, while majority of the respondents (88.3\%) were not aware of such policy. Likewise, most of the respondents (45\%) could not respond to whether employees Internet usage is being monitored while only $25 \%$ feels the monitoring was done occasionally. In the same vein, as much as $33.3 \%$ of the respondents were not aware of any blocking software, while only $20 \%$ have used blocking software to block unauthorized applications and websites.

Table 4: Internet Monitoring/Usage

\begin{tabular}{|l|l|l|}
\hline Variable & Measurement & Percent (\%) \\
\hline Does your institution monitor & All employees & 13.3 \\
\cline { 2 - 3 } or review website connections & Selected job categories & 20.0 \\
\cline { 2 - 3 } & Not practiced & 66.7 \\
\cline { 2 - 3 } & Total & 100 \\
\hline \multirow{4}{*}{$\begin{array}{l}\text { Internet use a written policy on } \\
\text { Yes }\end{array}$} & 11.7 \\
\cline { 2 - 3 } & No & 88.3 \\
\cline { 2 - 3 } & No response & 0.0 \\
\cline { 2 - 3 } & Total & 100 \\
\hline \multirow{4}{*}{$\begin{array}{l}\text { If mow would you categorize the } \\
\text { monitoring }\end{array}$} & Ongoing/regular & 8.3 \\
\cline { 2 - 3 } & Routine & 16.7 \\
\cline { 2 - 3 } & Occasional & 25.0 \\
\cline { 2 - 3 } & Specified & 5.0 \\
\cline { 2 - 3 } & No response & 45.0 \\
\cline { 2 - 3 } & Total & 100 \\
\hline \multirow{4}{*}{$\begin{array}{l}\text { Does your institution use blocking } \\
\text { software }\end{array}$} & Yes & 20.0 \\
\cline { 2 - 3 } & No & 46.7 \\
\cline { 2 - 3 } & Don't know & 33.3 \\
\cline { 2 - 3 } & Total & 100 \\
\hline
\end{tabular}

From table 5, the result shows that the most blocked applications are pornography (74.9\%), online gaming sites $(59 \%)$, social networking sites $(46.4 \%)$ and downloading music, video and picture $(44.8 \%)$. It also shows that $96.7 \%$ of the organizations did not block News sites. 
Table 5: Which of the following is restricted?

\begin{tabular}{|c|c|c|}
\hline Variables & \multirow[t]{2}{*}{ Yes (\%) } & \multirow[t]{2}{*}{ No (\%) } \\
\hline Which of the following is restricted? & & \\
\hline $\begin{array}{l}\text { Downloading video/pictures/music(YouTube, } \\
\text { 4shared) }\end{array}$ & 44.8 & 55.2 \\
\hline $\begin{array}{l}\text { social networking sites (facebook, twitter, linkedln, } \\
\text { hi5) }\end{array}$ & 46.4 & 53.6 \\
\hline Pornography sites & 74.9 & 25.1 \\
\hline online gaming sites & 59.0 & 41.0 \\
\hline $\begin{array}{l}\text { News(Punch , Tribune, 234NEXT, Sahara reports, } \\
\text { Guardian, etc) }\end{array}$ & 3.3 & 96.7 \\
\hline Yahoo messenger & 38.8 & 61.2 \\
\hline Online mail services (yahoomail, Gmail, Hotmail, etc.) & 33.9 & 66.1 \\
\hline Skype & 37.2 & 62.8 \\
\hline Blog sites & 36.1 & 63.9 \\
\hline Others & 11.5 & 88.5 \\
\hline
\end{tabular}

Table 6 shows that the common problems experienced by the institution with regard to employee Internet misuse are: computer virus due to heavy download $(76.3 \%)$, excessive chatting that is non-work related $(73.2 \%)$, downloading of music/ pictures/ videos (61.2\%), playing games (37.2\%), and accessing pornography at work (22.1\%).

Table 6: Problem with regard to employee Internet use

\begin{tabular}{|l|c|c|}
\hline Variables & \multirow{2}{*}{ Yes (\%) } & \multirow{2}{*}{ No (\%) } \\
\cline { 1 - 1 } Has your institution experienced problem & & \\
\hline Accessing pornography at work & 22.1 & 77.9 \\
\hline Downloading of music/pictures/video & 61.2 & 38.8 \\
\hline Computer virus due to heavy download & 76.6 & 23.4 \\
\hline Playing games & 37.2 & 62.8 \\
\hline Excessive chatting that is non-work related & 73.2 & 26.8 \\
\hline Other types of problem & 4.9 & 95.1 \\
\hline
\end{tabular}

From table 7 , the result shows that $9.1 \%$ of the institution management has ever disciplined an employee on misuse of office Internet facilities and $90.9 \%$ has not disciplined any employee. It also shows that $5.4 \%$ have ever disciplined an employee for misuse of institutional web sites and $94.6 \%$ has not disciplined an employee on misuse of institutional web sites.

Table 7: Policy Compliance and Discipline

\begin{tabular}{|l|l|l|}
\hline Variables & Yes (\%) & No (\%) \\
\hline $\begin{array}{l}\text { Has your institution ever disciplined an employee on misuse of } \\
\text { office Internet facilities? }\end{array}$ & 9.1 & 90.9 \\
\hline $\begin{array}{l}\text { Has your institution ever disciplined for misuses of institution } \\
\text { web sites? }\end{array}$ & 5.4 & 94.6 \\
\hline
\end{tabular}

From table 8 , the result shows that none of the employee has record of dismissal on misuse of office Internet facilities. It also revealed that $25.6 \%$ have formal warning and $68.5 \%$ of the respondents choose not to response. While $3.2 \%$ of employees have been dismissed for misusing of institutional web sites and $25.2 \%$ have formally warned their employee on misuse of office Internet facilities. And 70\% of the respondents have no response on the type of disciplinary action taken against misuse of institutional web sites. It was also discovered from the research that most of the employees have not been dismissed from misuse of Internet facilities. However 3.2\% of the employees recorded dismissal from the abuse of institutional web sites. This may be due to the fact that the management have not really established monitoring the use of Internet by employees in the institution. 
Table 8: Type of discipline

\begin{tabular}{|l|c|c|c|c|c|}
\hline Variables & $\begin{array}{c}\text { Dismissal } \\
(\%)\end{array}$ & $\begin{array}{c}\text { Formal } \\
\text { Warning } \\
(\%)\end{array}$ & $\begin{array}{c}\text { Informal } \\
\text { Warning } \\
(\%)\end{array}$ & $\begin{array}{c}\text { Other form of } \\
\text { discipline (\%) }\end{array}$ & $\begin{array}{c}\text { No } \\
\text { response } \\
(\%)\end{array}$ \\
\hline $\begin{array}{l}\text { What form of discipline was } \\
\text { taken on misuse of office Internet } \\
\text { facilities }\end{array}$ & 0 & 25.6 & 4.3 & 1.6 & 68.5 \\
\hline $\begin{array}{l}\text { What form of discipline was } \\
\text { taken on misuse of institutional } \\
\text { web sites }\end{array}$ & 3.2 & 25.2 & 1.6 & 0 & 70 \\
\hline
\end{tabular}

The result from table 9 below shows that at $p<0.05$, there is a positive and significant relationship between monitoring of the use of Internet by employee and management policy $(p=0.026, B=0.487)$. Also there is a negative significance in the monitoring use of Internet by employee and problem encountered in miss-using of Internet facility $(p=0.022, B=-0.508)$. Therefore, the null hypothesis was rejected and the alternative hypothesis was accepted that: there is significant relationship between monitoring of employees' Internet usage and awareness of policy on monitoring in LAUTECH, Ogbomoso.

Table 9: Regression Analysis Result

\begin{tabular}{|l|c|c|c|}
\hline Predictor Variables & B & Sig. Level & R Square \\
\hline Management Policy & 0.487 & 0.026 & 0.919 \\
Miss-Use of Internet Facility & -0.508 & 0.022 & \\
& & & \\
\hline \multicolumn{2}{|l|}{ Dependent Variable = Use of Internet by employee } \\
\hline
\end{tabular}

\section{DISCUSSION OF FINDINGS}

The results of the study shows that the institution surveyed have Internet access and mostly make use of the Local Area Network and Direct Subscriber License which shows that access to the Internet is not a problem within the institution. More so, over half of the employees have access to Internet. This agrees with what Alampay and Hechanova (2010) described in a similar study in the Philippines that higher percentage of access was granted to all employees. It also shows that only few restrictions were given to Internet accessibility but mostly the employees were given complete access. During interview conducted with the institution management, it was claimed that internet monitoring policy was in place but more than half of the respondents were not aware that monitoring of the use of Internet is practiced in the institution. This finding negate Alampay (2012) which stated that majority of organizations studied in Philippine monitored employee Internet usage.

Blocking of pornography sites is common but it has not however dissuaded people from trying to access such content as evident from the results of the study. Almost all the institution block pornography and online gaming sites as these two sites can reduce employees' productivity level and also lead to lack of concentration and time wastage which is precious to the organisation. This agrees with the findings of Deisz (2005) on Norwegian institution that reported that $73 \%$ of Norway active adult Internet users accessed the Web at least once from work, $41 \%$ access the Web a majority of the time at work, and $15 \%$ go online exclusively at work.

It was discovered that most of the problem encountered from the misuse of Internet facility in the institution is virus. The finding was supported by (Deisz, 2005) that there are several means of detecting, containing and deleting malware, they still cannot protect the computer systems before they are exposed to the threat. The result shows that, the incidence of indiscipline is higher, while only a few who agreed to ever disciplining their employees on breaching these policies were on misuse of office Internet and misuse of institutional web sites. This finding contrasts a finding of the American Management Association (AMA) in 2005, which reported that approximately $38 \%$ of 2,100 major U .S companies check their employee's e-mail and $54 \%$ monitor Internet connections (Yulihasri, et al, 2006).

\section{CONCLUSIONS / SUGGESTIONS}

This study provided empirical data on monitoring employee use of the Internet in Ladoke Akintola University of technology Ogbomoso, Oyo State, Nigeria. Based on the findings of this study, it could be concluded that most of the respondents have access and use Internet for their work. More so, Internet monitoring is not well established 
in the institution. Virus infections during downloading on the Internet was the major concern of most of the respondents and it can be concluded as the reason why the institution management blocked access to pornography and online gaming sites but not news sites. $73.2 \%$ agreed that excessive chatting that is non-work related is the predominant problem experienced with regard to misuse of Internet by the employees. This study basically considered monitoring of employees use of Internet in Ladoke Akintola University of Technology, Ogbomoso Oyo State, Nigeria. Also, since it is not certain from the study whether the institution has a written policy on regulation or monitoring of employees' Internet usage, there is a need for a written policy on regulation of Internet usage. There is also the need for the school's management to make this policy, if so formulated, known to all employees. Lastly, there is need by the school's ICT centre to install on their server, filtering software or malware to block some of the not too useful social networking media such as Badoo, Twoo, etc. More studies are needed to explain the pattern of Internet adoption by employee as there are different adoption stages to technology.

\section{REFERENCES}

Adeya B. \& Oyeyinka, C .N. (2002). The Internet in African Universities: Case Study of Kenya and Nigeria. NU/INTECH Discussion Paper.

Adewoye, J, Ayo, C.K, Oni, A.A and Adebiyi, A.A. (2011). The impact of IT investment delivery of Ladoke Akintola University. Journal of Emerging Trends in Educational Research and Policy Studies 2(11): pp.60-66.

Aina, L.O. (2004). Library and information science text for Africa. Ibadan, Nigeria: Third World Information Services Limited, p. 324

Alampay, E.A, and Hechanova, R.M. (2010) Monitoring Employee Use of the Internet in Philippine Organizations: The Electronic Journal on Information Systems in Developing Countries, 40(5), 1-20.

American Management Association (2008). 2007 Electronic Monitoring \& Surveillance Survey Retrieved April 28, 2014, from: http://press.amanet.org/press-releases/177/2007-electronicmonitoring-surveillance-survey.

American Management Association (2005, 2001), AMA Research: Workplace Monitoring and Surveillance, 1999, 2000, 2001 and 2005. Accessed on August 4, 2014 from: www.amanet.org/research/archive 2001 1999.htm.

American Management Association (2003). Survey on Workplace E-Mail Reveals Disasters in the Making, May 28, 2003; Accessed on August 4, 2014 from: www.amanet.org/press/amanews/Email Survey2003.htm.

Awoleye, O.M., Siyanbola, W.O., \& Oladipo, F.O. (2008) Adoption Assessment of Internet Usage amongst Undergraduates in Nigeria Universities- A Case Study Approach. Journal of Technology Management and Innovation (JOTMI Research Group) Santiago Chile. 3(001), 84-89.

Bhatt, G. D. (2000). Organizing knowledge in the knowledge development cycle. Journal of Knowledge Management, 4, 15-26.

Bezek, P.J., \& Britton, S.M. (2001). Employer monitoring of employee Internet use and e-mail: MEALEY'S Cyber Tech Litigation Report, 2, Retrieved April 28, 2014, from:

http://www.foleybezek.com/art.InternetFile.pdf.

Chalykoff, J. \& Kochan, T. (1989) Computer-aided monitoring: Its influence on employee job satisfaction and turnover. Personnel Psychology 42, 807-834.

Court, L., \& Warmington, C. (2004). The workplace privacy myth: why electronic monitoring is here to stay. Employment and Labor Law, 1(1), 1-20.

Crimmins, J. Even federal judges come under surveillance when online. Chicago Daily Law Bulletin 147, 159 (Aug. 14, 2001).

Deisz, J. (2005). Internet filtering and how it affects security, efficiency and thriving in Norwegian Companies. Msc Thesis published with Royal Institute of Technology (KTH), Stockholm. Retrieved 13th November, 2012 from: http://www.nislab.hig.no

Flynn, N. (2009) The e-Policy Handbook ( ${ }^{\text {nd }}$ Ed) - Rules and Best Practices to Safely Manage Your Company's Email, Blogs, Social Networking and Other Electronic Communication Tools, AMACOM books.

Frayer, C. (2002). Employee privacy and internet monitoring: balancing workers' rights and dignity with legitimate management interests. Business Lawyer, 57(2), 857 - 878.

Gahtan, A. (2002) Monitoring Employee Communications. The Cyber law Encyclopedia. Retrieved January 06, 2012 from: http://www.gahtan.com/alan/articles/monitor.htm

Gupta, J. (2004) Improving Workers' Productivity and Reducing Internet Abuse, The Journal of Computer Information Systems, 44, 2, 74-78.

Guthrie, R. \& Gray, P. (1996). Junk Computing: Is it bad for an organization? Information System Management, 23-28.

Hart, K. (2000). THE MEMORY BANK: Money in an Unequal World. Cambridge, London:Profile Books Ltd.

Hechanova, M.R. \& Estuar, M.R (2010). Are You Living a Computer-Connected Life? in Hechanova, M.R., Franco, E.P. and Reyes, R. (Eds). Pinoy@Work. Manila, Philippines: Ateneo de Manila University Loyola Schools Office of Research and Publications. 
Horrigan, J. and Lee, R. (2006) The Internet's Growing Role in Life's Major Moments. Accessed on Dec. 10, 2012 from: http://www.pewlnternet.org/pdfs/PIP Major\%20Moments 2006.pdf.

Leiner, B.M.; Kahn, R. E.; Postel, J.; Clark, D.D.; ...Roberts, L.G. (2009). A Brief history of the Internet. ACM SIGCOMM Computer Communication Review, 39(5), 4-7.

Madueme, I. S. (2010) Evaluation of the Impact of Information Communication Technology on Banking Efficiency Using the Transcendental Logarithmic Production function and Camel Rating. International Journal of Engineering Science and Technology, 2(1), 1-6.

Marshall, P. (2001). Are tougher laws needed to protect citizens? Privacy under Attack, 11(19), 1-30.

McEvoy, S. (2002). E-mail and Internet Monitoring and the Workplace: Do Employees have a Right to Privacy? , Communications and the Law, 24(2), 69-84.

Neilson Net Rankings (2006). U.S. Online Population Internet Use. Accessed on August 6, 2014 from: www. nielsen-netratings.com/pr/pr 021218.pdf.

Nord, G.D.; McCubbins, T.F. \& Nord, J.H. (2006). E-Monitoring in the workplace: privacy, legislation, and surveillance software. Communications of the ACM, 49(8), 73-77.

Peters, T. A. (1999). Computerized Monitoring and Online Privacy. Jefferson, North Carolina: McFarland \& Company.

Pew Internet Survey (2002). Pew Internet \& American Life, getting serious online: as Americans gain experience they use the web more at work, write e-mails with more significant content, perform more online transactions, and pursue more serious activities. Accessed on August 6, 2014 from: www. pewinternet.org/reports/toc. asp?Report=55.

Ojedokun, A.A (2001). Internet Access and Usage by Students of the University of Botswana: African Journal of Library, Archive and Information Science, 11(2), 97-109.

Omolase, C. O., Ihemedu, C. O., Ogunleye, T. O., \& Omolase, B. O. (2010). Use of Internet for Health Information amongst Medical Practitioners in a Nigerian Community. TAF Preventive Medicine Bulletin, 9(2), 93-98.

Simmers, C. A. (2002). Aligning Internet usage with business priorities: Regulating Internet activities so that targeted outcomes remain within acceptable limits. Communications of the ACM, 45(1), 71-74.

United Nations Publication (2007) Internet Use For Business Development: An Introductory Set Of Training Modules For Policymakers. Bangkok 2007

Urdan, T., and C. Weggen (2000) "Corporate e-learning: exploring a new frontier". http:www.elearning//publicaties/marktonderzock/New_Frontier.pdf. Accessed on Dec. 10, 2012.

Ureigho, R.J, Oroke, G.U, and Ekruyota, G.O. (2006). The Impact of Internet Usage: A Case Study of Delta State (Nigeria) Tertiary Institutions. Journal of Scientific Research and Essay, 1(2), 054-056.

Yerby, J. (2013). Legal and ethical issues of employee monitoring. Online Journal of Applied Knowledge Management, 1(2), 44-55.

Yulihasri, Ramayah T., Norzalila J., \& Amlus I., (2006) Use and Misuse of the Internet in the Malaysian Workplace: Preliminary Findings from an Exploratory Study IAMOT, 2006.

Zuboff, S. (1988). In the Age of the Smart Machine. New York: Basic Books.

Cite this Article: Sobalaje AJ, Adigun GO and Arinola AA (2015). Monitoring Employees' Use of the Internet in Ladoke Akintola University of Technology Ogbomoso, Oyo State, Nigeria. Greener Journal of Social Sciences, 5(2):042-050, http://doi.org/10.15580/GJSS.2015.2.291114398. 